American Journal of Pharmaceutical Education 2020; 84 (12) Article 7981.

\title{
RESEARCH
}

\section{Perceived Value of Teaching and Learning Curriculum Programs Among Pharmacy Practice Department Chairs}

\author{
Robert D. Beckett, PharmD, ${ }^{\mathrm{a}}$ Alex N. Isaacs, PharmD, ${ }^{\mathrm{b}}$ Kaitlin J. Montagano, PharmD, \\ Amy H. Sheehan, PharmD, ${ }^{b}$ Darin C. Ramsey, PharmD, ${ }^{c}$ Tracy Sprunger, PharmD ${ }^{c}$ \\ ${ }^{a}$ Manchester University, College of Pharmacy, Natural and Health Sciences, Fort Wayne, Indiana \\ ${ }^{\mathrm{b}}$ Purdue University, College of Pharmacy, West Lafayette, Indiana \\ ${ }^{c}$ Butler University, College of Pharmacy and Health Sciences, Indianapolis, Indiana \\ Submitted January 15, 2020; accepted August 20, 2020; published December 2020.
}

Objective. To determine the perceived value that pharmacy practice department chairs ascribe to pharmacy faculty candidates having completed a teaching and learning curriculum (TLC) program and related activities.

Methods. An 18-item survey instrument was created that was intended to capture the overall impressions of pharmacy practice chairs regarding the value of TLC programs, relative importance compared to other accomplishments (eg, residency completion, board certification), and importance of specific activities. Following pilot testing and establishment of intra-rater reliability, invitations to complete the electronic survey instrument were sent to pharmacy practice chairs (or their equivalent) at accredited Doctor of Pharmacy (PharmD) programs in the United States.

Results. Of the 127 pharmacy practice chairs invited, 53 completed the survey (response rate of $41.7 \%$ ). The majority of respondents held a PharmD degree (90.6\%), had been in their role of chair for zero to five years $(60.4 \%)$, and represented a private institution $(54.7 \%)$. The majority of respondents who answered the question (32 of 49) felt it was very important or important (16.3\% and $49.0 \%$, respectively) that teaching experiences be completed within a formal teaching and learning curriculum program. These programs were believed to be most important for candidates with less than five years of professional experience. Teaching and learning curriculum programs were not deemed to be more important than other accomplishments by most responders. The perceived most important TLC program activities were instruction on didactic and experiential teaching strategies, and experience developing learning objectives, developing examination items, evaluating examination results, and facilitating case conferences or practice laboratory activities.

Conclusion. Teaching and learning curriculum programs may provide the foundational experiences needed for pharmacy graduates to stand out among other candidates, although department chairs' perceptions of the value of teaching and learning curriculum experiences varied.

Keywords: teaching and learning curricula, residency training, continuing education, survey research

\section{INTRODUCTION}

Teaching and learning curriculum programs serve an integral role in the development of teaching- and learningrelated educational skills in pharmacy residents and fellows, preparing these postgraduate pharmacists to meet employer needs for qualified pharmacy faculty. ${ }^{1-4}$ American Society of Health-System Pharmacists (ASHP) accreditation standards for postgraduate year one (PGY1) pharmacy residency

Corresponding Author: Robert D. Beckett, Manchester University College of Pharmacy, 10627 Diebold Rd., Fort Wayne, IN 46845. Tel: 260-470-2663. Email: rdbeckett@, manchester.edu programs include specific competencies for teaching and learning, and TLC programs are often incorporated as requirements for pharmacy residency completion in order to facilitate resident mastery of teaching-related competencies. ${ }^{5}$ As such, the availability of programs has grown significantly over the last 15 years, ${ }^{6-17}$ with approximately 70 programs affiliated with schools and colleges of pharmacy throughout the United States available., ${ }^{3,4}$ As the recruitment of qualified faculty members is vital to the ongoing success of pharmacy education, programs on TLC can play a vital role in preparing faculty members to meet these expectations. 


\section{American Journal of Pharmaceutical Education 2020; 84 (12) Article 7981.}

Most TLC programs are one year long and include participation in didactic seminars and completion of required experiences in a variety of teaching settings. ${ }^{3,4}$ Although formal accreditation for these programs does not exist, most programs across the country follow best practices published by ASHP, the American Association of Colleges of Pharmacy (AACP), and the American College of Clinical Pharmacy (ACCP) for the development, conduct, and evaluation of TLC programs. ${ }^{3}$ Common requirements of the resident include facilitating student learning via small group discussion, delivering didactic lectures, creating learning assessments, and precepting or co-precepting advanced pharmacy practice experiences (APPEs) and introductory pharmacy practice experience (IPPEs). Participants also are often required or encouraged to develop and maintain a teaching portfolio.

The perceived benefits of participating in teachingrelated activities, including completion of a formal teaching and learning curriculum program, have been widely documented by residents, preceptors, and faculty members. ${ }^{9,18-28}$ Reported benefits include improved time management skills, increased confidence and comfort level with teaching activities, and successful attainment of a faculty position post-residency. Availability of a TLC program has also been used as a recruitment tool to attract prospective residency candidates. ${ }^{2}$ A survey of residency program directors indicated that the majority placed a high value on developing future pharmacy educators. However, only a minority of respondents reported that completing a formal teaching certificate program was of high value. ${ }^{29}$

The value of TLC programs has been expressed by many stakeholders and these programs have been proposed as a means to help develop pharmacy residents to meet employer needs for qualified pharmacy faculty members. ${ }^{2,9,18-28}$ However, it is unclear whether these programs are valued by those in academia who are responsible for faculty employment. Therefore, the objective of this study was to determine pharmacy practice department chairs' perceptions of the value of TLC programs and related activities when making hiring decisions.

\section{METHODS}

A list of pharmacy practice chairs at US Doctor of Pharmacy programs accredited by the Accreditation Council for Pharmacy Education (ACPE) ${ }^{30}$ was developed through a review of faculty rosters on program websites. If a pharmacy practice chair was not identifiable, the faculty member with the closest related position was selected. This was most commonly a department head or a faculty member in another department, such as clinical pharmacy or clinical sciences. A list of email addresses was generated by a single investigator and double-checked by a second investigator.
An 18-item electronic survey instrument (available from the corresponding author) was designed by the investigators to administer to pharmacy practice chairs. The survey addressed the faculty members' overall impressions of the value of teaching and learning curriculum programs, the value of having completed a program in teaching and learning curriculum compared to a candidate's other accomplishments, and the value of specific activities within a teaching and learning curriculum. Specific activities were informed by the results of a literature search. ${ }^{4,6-28,31,32}$ This report focuses on quantitative survey items and results.

A final draft of the survey was piloted by two pharmacy practice chairs for assessment of face and content validity, and to establish intra-rater reliability. ${ }^{33-35}$ Pilot testers were also asked to provide feedback in the form of comments or suggestions regarding survey content or construction.

Intra-rater reliability was established with a test-retest approach using a two-way mixed effects model based on absolute agreement of responses using average measures. $^{33,35}$ The two pilot testers were given the survey a second time one month following completion of the first administration. Intraclass coefficients were calculated using all survey items, with values greater than 0.75 suggesting good reliability and greater than 0.9 suggesting excellent reliability. ${ }^{35}$ On pilot testing, the survey demonstrated good intra-rater reliability (intraclass correlation coefficient 0.76 ). Following pilot testing, validation, and reliability assessment, the project was deemed exempt by the Institutional Review Board (IRB) at Purdue University.

An electronic invitation to complete the survey was distributed in February 2019 via email to the identified pharmacy practice chairs and again in June 2019 to those who had not responded. Participants were informed that participation was voluntary, and confidential, and that they could stop the survey at any time without penalty, and that completing the survey would take about 10 minutes. Participants had four weeks to submit the survey. Up to three reminders were sent to those who had not yet responded. ${ }^{36}$ Five $\$ 100$ gift cards were randomly distributed to incentivize participation.

Nonresponse bias was evaluated by comparing the demographics of responders with the demographics of responders in previously published surveys of pharmacy practice department chairs, as well as to data available from AACP and ACPE. ${ }^{37-41}$ Participants were defined as all individuals who began the survey and completers were defined as all individuals who responded to any questions beyond providing basic demographics. The primary analysis used data from completers to calculate response rate, describe demographics, and measure results, with no imputation used for missing data. Results were analyzed 


\section{American Journal of Pharmaceutical Education 2020; 84 (12) Article 7981.}

using descriptive statistics. The study adhered to best practices for survey research. ${ }^{36,38,39}$

\section{RESULTS}

Of the 133 invitations sent out, five were returned undeliverable. Fifty-eight faculty members completed the survey, for an initial response rate of $45.7 \%$. Removal of five surveys from individuals who were not current or former department chairs left 53 usable survey instruments, resulting in a final response rate of $41.7 \%(53 /$ 127). All but one of the 53 completers were current chairs. Participant demographics and institutional characteristics are provided in Table 1.

The majority of completers (32 of 49) felt it was very important or important (16.3\% and $49.0 \%$, respectively) that residents complete teaching experiences within a formal TLC program. A substantial minority (20.4\%) of these respondents felt this was fairly important. The importance of a faculty candidate having completed a TLC program based on type of position sought is described in Table 2. Completion of a TLC program was judged to be most important for recent residency or fellowship graduates and practicing pharmacists with zero to five years of experience, with greater importance placed on the offer to interview than the eventual offer of employment. Completer ratings of the relative importance of TLC programs compared to other qualifications and factors in faculty recruitment are provided in Table 3. Respondents rated TLC programs as having similar importance to a cover letter or letter of intent and board certification (the latter for clinical faculty members only). The TLC programs were generally perceived to be somewhat less important than all other factors, although results varied greatly.

The importance of various activities included in a TLC program, as rated by completers, is presented in Table 4 . More than $70 \%$ of completers rated the following items as important or very important: experience developing learning objectives, instruction on didactic teaching strategies, instruction on experiential teaching strategies, experience developing examination items, experience evaluating examination results, and experience facilitating case conference or practice laboratory activities. Activities rated as less important included delivering distance education and teaching non-pharmacy learners.

\section{DISCUSSION}

Teaching and learning curricula provide pharmacy residents and fellows with foundational teaching and scholarship exposure. ${ }^{1-4,6-17,19}$ While it is important to evaluate the quality and impact of these programs, it is also necessary to seek input from employers about the value of these programs in recruiting qualified pharmacy
Table 1. Demographic Information and Institutional Characteristics of Pharmacy Practice Department Chairs Who Participated in a Survey Regarding Their Perceived Value of Teaching and Learning Curriculum Programs $(\mathrm{N}=53)$

\begin{tabular}{|c|c|}
\hline Variable & Completers, ${ }^{\mathrm{a}}$ No. (\%) \\
\hline Current department chair ${ }^{\mathrm{b}}$ & $52(98.1)$ \\
\hline \multicolumn{2}{|l|}{ Time in chair role } \\
\hline 0 to 5 years & $32(60.4)$ \\
\hline 6 to 10 years & $15(28.3)$ \\
\hline 11 to 15 years & $4(7.5)$ \\
\hline 16 to 20 years & $2(3.8)$ \\
\hline \multicolumn{2}{|l|}{ Gender } \\
\hline Female & $30(56.6)$ \\
\hline Male & $23(43.4)$ \\
\hline \multicolumn{2}{|l|}{ Race and ethnicity } \\
\hline White & $45(84.9)$ \\
\hline Hispanic/Latino & $4(7.5)$ \\
\hline Asian or Asian American & $3(5.7)$ \\
\hline American Indian or Alaska Native & $1(1.9)$ \\
\hline \multicolumn{2}{|l|}{ Highest earned degree } \\
\hline PharmD & $48(90.6)$ \\
\hline $\mathrm{PhD}$ & $3(5.7)$ \\
\hline Master's & $1(1.9)$ \\
\hline BSPharm & $1(1.9)$ \\
\hline \multicolumn{2}{|l|}{ Past TLC program experience ${ }^{c}$} \\
\hline Organizer or presenter & $38(71.7)$ \\
\hline Mentor & $29(54.7)$ \\
\hline Participant & $11(20.8)$ \\
\hline \multicolumn{2}{|l|}{ Typical graduating class size } \\
\hline 100 or fewer & $32(60.4)$ \\
\hline 101 to 150 & $15(28.3)$ \\
\hline 151 to 200 & $4(7.5)$ \\
\hline 201 to 250 & $1(1.9)$ \\
\hline 251 or greater & $1(1.9)$ \\
\hline \multicolumn{2}{|l|}{ Institution type } \\
\hline Private & $29(54.7)$ \\
\hline Public & $24(45.3)$ \\
\hline \multicolumn{2}{|l|}{ Institution region } \\
\hline South & $24(46.2)$ \\
\hline Midwest & $16(30.8)$ \\
\hline Northeast & $6(11.5)$ \\
\hline West & $6(11.5)$ \\
\hline \multicolumn{2}{|l|}{ Number of graduated classes } \\
\hline 0 to 5 & $13(24.5)$ \\
\hline 6 to 15 & $9(17.0)$ \\
\hline 16 to 25 & $8(15.1)$ \\
\hline 26 to 50 & $2(3.8)$ \\
\hline 51 or more & $21(39.6)$ \\
\hline \multicolumn{2}{|c|}{$\begin{array}{l}\text { Abbreviations: PharmD }=\text { Doctor of Pharmacy, } \mathrm{PhD}=\text { Doctor of Phi- } \\
\text { losophy, BSPharm }=\text { Bachelor of Science in Pharmacy, TLC }=\text { teach- } \\
\text { ing and learning curriculum } \\
\text { a Individuals who responded to any questions beyond providing basic } \\
\text { demographics } \\
{ }^{b} \text { One former department chair completed the survey for their } \\
\text { institution } \\
{ }^{c} \text { Non-exclusive }\end{array}$} \\
\hline
\end{tabular}




\section{American Journal of Pharmaceutical Education 2020; 84 (12) Article 7981.}

Table 2. Pharmacy Practice Department Chairs' Perceptions of the Importance of Pharmacy Faculty Candidates Having Completed a Teaching and Learning Curriculum Program ${ }^{\mathrm{a}}$

\begin{tabular}{|c|c|c|c|c|c|}
\hline & $\begin{array}{l}\text { Type of } \\
\text { Faculty } \\
\text { Position }\end{array}$ & $\begin{array}{l}\text { Very Important } \\
\text { or Important, } \\
\text { No. }(\%) \\
\end{array}$ & $\begin{array}{c}\text { Fairly } \\
\text { Important, } \\
\text { No. }(\%) \\
\end{array}$ & $\begin{array}{c}\text { Slightly Important } \\
\text { or Not Important, } \\
\text { No. }(\%)\end{array}$ & $\begin{array}{l}\text { Median } \\
(I Q R)^{b}\end{array}$ \\
\hline \multicolumn{6}{|l|}{$\begin{array}{l}\text { For extending an interview } \\
\text { offer }\end{array}$} \\
\hline $\begin{array}{l}\text { Recent PGY1 or PGY1 } \\
\text { residency or fellowship } \\
\text { graduate }\end{array}$ & $\begin{array}{l}\text { Clinical } \\
\quad \text { Non-Clinical }\end{array}$ & $\begin{array}{l}35(66.0) \\
35(66.0)\end{array}$ & $\begin{array}{r}9(17.0) \\
11(20.8)\end{array}$ & $\begin{array}{l}9(17.0) \\
7(13.2)\end{array}$ & $\begin{array}{l}2(1 \text { to } 3) \\
2(1 \text { to } 3)\end{array}$ \\
\hline $\begin{array}{l}\text { Practicing pharmacist with } \\
0-5 \text { years of experience }\end{array}$ & $\begin{array}{l}\text { Clinical } \\
\text { Non-Clinical }\end{array}$ & $\begin{array}{l}29(55.8) \\
28(53.8)\end{array}$ & $\begin{array}{l}12(23.0) \\
13(25.0)\end{array}$ & $\begin{array}{l}11(21.2) \\
11(21.2)\end{array}$ & $\begin{array}{l}2(2 \text { to } 3) \\
3(2 \text { to } 4)\end{array}$ \\
\hline $\begin{array}{l}\text { Practicing pharmacist with } \\
\text { more than } 5 \text { years of } \\
\text { experience }\end{array}$ & $\begin{array}{l}\text { Clinical } \\
\quad \text { Non-Clinical }\end{array}$ & $\begin{array}{l}20(37.7) \\
16(30.2)\end{array}$ & $\begin{array}{l}18(34.0) \\
20(37.7)\end{array}$ & $\begin{array}{l}15(28.3) \\
17(32.1)\end{array}$ & $\begin{array}{l}3(2 \text { to } 4) \\
3(2 \text { to } 4)\end{array}$ \\
\hline $\begin{array}{l}\text { Currently faculty member } \\
\text { with } 0-5 \text { years of } \\
\text { experience }\end{array}$ & $\begin{array}{l}\text { Clinical } \\
\text { Non-Clinical }\end{array}$ & $\begin{array}{l}14(26.9) \\
18(35.5)\end{array}$ & $\begin{array}{l}20(38.5) \\
16(31.4)\end{array}$ & $\begin{array}{l}18(34.6) \\
17(33.3)\end{array}$ & $\begin{array}{l}3(2 \text { to } 4) \\
3(2 \text { to } 4)\end{array}$ \\
\hline Recent $\mathrm{PhD}$ graduate & Non-Clinical & $17(32.7)$ & $15(28.8)$ & $20(38.5)$ & $3(2$ to 4$)$ \\
\hline \multicolumn{6}{|l|}{$\begin{array}{l}\text { For extending an offer of } \\
\text { employment }\end{array}$} \\
\hline $\begin{array}{l}\text { Recent PGY1 or PGY2 } \\
\text { residency or fellowship } \\
\text { graduate }\end{array}$ & & $24(49.0)$ & $7(14.3)$ & $18(36.7)$ & $3(2$ to 4$)$ \\
\hline $\begin{array}{l}\text { Practicing pharmacist with } \\
0-5 \text { years of experience }\end{array}$ & & $15(30.6)$ & $16(32.7)$ & $18(36.7)$ & 3 (2 to 4$)$ \\
\hline $\begin{array}{l}\text { Practicing pharmacist with } 5 \\
\text { or more years of experience }\end{array}$ & & $11(22.5)$ & $10(20.4)$ & $28(57.1)$ & 4 (3 to 4$)$ \\
\hline $\begin{array}{l}\text { Current faculty member with } \\
0-5 \text { years of experience }\end{array}$ & & $16(33.3)$ & $9(18.8)$ & $23(47.9)$ & $3(2$ to 4$)$ \\
\hline Recent $\mathrm{PhD}$ graduate & & $11(22.4)$ & $14(28.6)$ & $24(49.0)$ & 3 (3 to 4$)$ \\
\hline
\end{tabular}

Abbreviations: $\mathrm{PGY} 1=$ postgraduate year $1, \mathrm{PGY} 2=$ postgraduate year $2, \mathrm{TLC}=$ teaching and learning curriculum

${ }^{a} \mathrm{~N}=53$ completers; however, not every completer answered every question

${ }^{\mathrm{b}}$ On a five-point scale where $1=$ very important, $2=$ important, $3=$ fairly important, $4=$ slightly important, and $5=$ not important

faculty members. Successful recruitment of qualified faculty members is not only important to individual institutions, but to the Academy as a whole. For candidates, experience provided by TLC programs is foundational to preparing them to successfully be hired as and transition into roles as pharmacy faculty members. Teaching and learning curriculum programs aim to provide this important experience.

This study is the first to evaluate the perceived value in the hiring process of a pharmacy faculty candidate having completed a TLC program. The findings highlight the importance of a candidate completing a TLC program, specifically pharmacists who are recent graduates or have less than five years of professional experience. Practice chairs reported that, on average, TLC programs are typically considered less important or somewhat less important than most other assessed qualifications or characteristics. Two exceptions, board certification and cover letter, were rated, on average, as having similar importance to TLC program completion. The reasons for this are unclear, but it may be because candidates completing postgraduate education may not be expected to already have obtained board certification. Cover letters can be helpful in getting to know candidates during the initial screening process but may not be strongly considered in the ultimate interview or hiring decision.

Specific activities within TLC programs that practice chairs believed were valuable included educational programming, mentorship, and tangible teaching and assessment opportunities in didactic, small-group, and experiential settings. Interestingly, experience in remote learning was one of the lowest rated specific items. Given the events in 2020 surrounding the novel coronavirus 2019 (COVID-19) pandemic, survey results obtained today might be quite different. The diverse educational opportunities afforded by TLC programs may provide the 


\section{American Journal of Pharmaceutical Education 2020; 84 (12) Article 7981.}

Table 3. Pharmacy Practice Department Chair Ratings of the Relative Importance of Teaching and Learning Curriculum Programs in the Faculty Recruitment and Hiring Process Compared to Other Qualifications or Characteristics ${ }^{\mathrm{a}}$

\begin{tabular}{|c|c|c|c|c|c|}
\hline $\begin{array}{l}\text { Qualifications or } \\
\text { Characteristics }\end{array}$ & $\begin{array}{c}\text { Faculty } \\
\text { Position } \\
\text { Type }\end{array}$ & $\begin{array}{l}\text { TLC More or } \\
\text { Somewhat More } \\
\text { Important } n(\%)\end{array}$ & $\begin{array}{c}\text { Similar } \\
\text { Importance } \\
\text { n (\%) }\end{array}$ & $\begin{array}{l}\text { TLC Somewhat } \\
\text { Less or Less } \\
\text { Important } \\
\text { n (\%) }\end{array}$ & Median (IQR) ${ }^{\mathbf{b}}$ \\
\hline \multirow{2}{*}{$\begin{array}{l}\text { Academic degree } \\
\text { beyond PharmD }\end{array}$} & Clinical & $7(13.2)$ & $12(22.6)$ & $34(64.2)$ & $2(1$ to 3$)$ \\
\hline & Non-Clinical & $5(9.6)$ & $14(26.9)$ & $33(63.5)$ & 2 (1 to 3$)$ \\
\hline \multirow[t]{2}{*}{ Board certification } & Clinical & $9(17.0)$ & $17(32.1)$ & $27(50.9)$ & 2 (1 to 3$)$ \\
\hline & Non-Clinical & $7(13.7)$ & $20(39.2)$ & $24(47.1)$ & 3 (2 to 3$)$ \\
\hline \multirow{2}{*}{$\begin{array}{l}\text { Cover letter or letter } \\
\text { of intent }\end{array}$} & Clinical & $10(19.2)$ & $21(40.4)$ & $21(40.4)$ & $3(2$ to 3$)$ \\
\hline & Non-Clinical & $9(17.3)$ & $20(38.5)$ & $23(44.2)$ & $3(2$ to 3$)$ \\
\hline \multirow{2}{*}{$\begin{array}{l}\text { Length of pharmacy } \\
\text { practice experience }\end{array}$} & Clinical & $7(13.2)$ & $13(24.5)$ & $33(62.3)$ & $2(1$ to 3$)$ \\
\hline & Non-Clinical & $5(9.6)$ & $13(25.0)$ & $34(65.4)$ & $2(1$ to 3$)$ \\
\hline \multirow{2}{*}{$\begin{array}{l}\text { PGY1 residency } \\
\text { completion }\end{array}$} & Clinical & $11(20.8)$ & $13(24.5)$ & $29(54.7)$ & $2(1$ to 3$)$ \\
\hline & Non- Clinical & $10(19.2)$ & $15(28.8)$ & $27(52.0)$ & $2(1.75$ to 3$)$ \\
\hline \multirow{2}{*}{$\begin{array}{l}\text { PGY2 residency } \\
\text { completion }\end{array}$} & Clinical & $9(17.3)$ & $11(21.2)$ & $32(61.5)$ & 2 (1 to 3$)$ \\
\hline & Non-Clinical & $8(15.4)$ & $13(25.0)$ & $31(59.6)$ & 2 (1 to 3$)$ \\
\hline \multirow[t]{2}{*}{ Fellowship completion } & Clinical & $11(20.8)$ & $11(20.8)$ & $31(58.4)$ & 2 (1 to 3$)$ \\
\hline & Non-Clinical & $8(15.4)$ & $13(25.0)$ & $31(59.6)$ & 2 (2 to 3$)$ \\
\hline \multirow{2}{*}{$\begin{array}{l}\text { Relevant pharmacy } \\
\text { practice experience }\end{array}$} & Clinical & $6(11.3)$ & $11(20.8)$ & $36(67.9)$ & 2 (1 to 3$)$ \\
\hline & Non-Clinical & $5(9.6)$ & $14(26.9)$ & $33(63.5)$ & 2 (1 to 3$)$ \\
\hline \multirow[t]{2}{*}{ Publications } & Clinical & $8(15.31)$ & $12(22.6)$ & $33(62.3)$ & 2 (1 to 3$)$ \\
\hline & Non-Clinical & $3(5.8)$ & $14(26.9)$ & $33(67.3)$ & $2(1$ to 3$)$ \\
\hline
\end{tabular}

${ }^{a} \mathrm{~N}=53$ completers; however, not every completer answered every question

${ }^{\mathrm{b}}$ On a 5-point scale where $1=\mathrm{TLC}$ less important, $2=\mathrm{TLC}$ somewhat less important, $3=$ similar importance, $4=\mathrm{TLC}$ slightly more important, and $5=$ TLC more important

PGY1 = Post-graduate year 1, PGY2= Post-graduate year 2, TLC $=$ Teaching and learning curriculum

foundation for program graduates to stand out among other pharmacy faculty candidates, although it is clear from these survey results that department chairs vary in their perceptions of the value of TLC experiences as a whole.

Most published literature on pharmacy TLC programs discusses the impact on the residents or fellows completing the program. Romanelli and colleagues reported that TLC program graduates self-reported they were more prepared to assume faculty roles; however, data on the graduates obtaining a position within higher education was not reported. ${ }^{8}$ Nappi described a TLC program and its impact, including that $13 \%$ of past graduates had secured a faculty position. ${ }^{13}$ This faculty attainment rate is in alignment with that noted in a study by Gettig and colleagues, where $7.5 \%$ of graduates obtained a faculty role within one year after program completion. ${ }^{9}$ Shin and colleagues found that over $60 \%$ of second-year pharmacy residents reported interest in academia at the beginning of their residency and $24 \%$ secured a faculty position by the end of their residency. ${ }^{42}$ Residents who completed a TLC program were more likely to apply for and accept a position within pharmacy education. In addition, several studies have reported that program participants also perceive the utility of TLC programs. ${ }^{6,7,8,22}$ For example, pretest and posttest evaluations conducted by Castellani and colleagues among 10 pharmacy residents completing a TLC program found that self-reported confidence in 24 of the 30 teaching abilities evaluated had significantly increased by the end of the program. ${ }^{6}$ Silvia and colleagues conducted a survey at the end of a seminar series for pharmacy residents and found that self-reported knowledge improved in all areas assessed. ${ }^{7}$ Similarly, Romanelli and colleagues reported that pharmacy residents' self-perceived effectiveness as a teacher and confidence in teaching abilities significantly increased following completion of a TLC program. ${ }^{8}$ These studies highlight the impact and utility of TLC programs from the perception of program graduates.

With many pharmacy residents and fellows pursuing TLC programs during training, it is vital for the Academy to perform market research analysis to evaluate employer perspectives in relation to other hiring variables for pharmacists who aspire to become pharmacy faculty members. ${ }^{41,43}$ The current study is the first to evaluate chair perceptions of the importance of a faculty candidate 


\section{American Journal of Pharmaceutical Education 2020; 84 (12) Article 7981.}

Table 4. Importance of Teaching and Learning Curriculum Activities According to Pharmacy Practice Department Chairs ${ }^{\mathrm{a}}$

\begin{tabular}{lccc}
\hline Activity & $\begin{array}{c}\text { Very Important or } \\
\text { Important n (\%) }\end{array}$ & $\begin{array}{c}\text { Fairly Important } \\
\mathbf{n ~ ( \% )}\end{array}$ & $\begin{array}{c}\text { Slightly Important or } \\
\text { Not Important n (\%) }\end{array}$ \\
\hline $\begin{array}{l}\text { Academic or professional misconduct } \\
\text { resolution }\end{array}$ & $24(47.1)$ & $10(19.6)$ & $17(33.3)$ \\
Case conference or PPL, facilitation & $37(72.5)$ & $8(15.7)$ & $6(11.8)$ \\
Case conference or PPL, primary instruction & $31(62.0)$ & $9(18.0)$ & $10(20.0)$ \\
Distance education delivery & $12(23.5)$ & $8(15.7)$ & $31(60.8)$ \\
Examination items, development & $43(84.3)$ & $7(13.7)$ & $1(2.0)$ \\
Examination items, evaluating results & $39(76.5)$ & $11(21.6)$ & $1(2.0)$ \\
Experiential rotation co-precepting & $35(70.0)$ & $9(18.0)$ & $6(12.0)$ \\
Experiential rotation precepting & $23(46.0)$ & $15(30.0)$ & $12(24.0)$ \\
Experiential teaching, facilitating daily & $35(68.6)$ & $7(13.7)$ & $9(17.6)$ \\
$\quad$ activities & $35(68.6)$ & $12(23.5)$ & $4(7.8)$ \\
Experiential teaching, facilitating periodic & & & \\
$\quad$ activities & $46(90.2)$ & $3(5.9)$ & $2(3.9)$ \\
Instruction on didactic teaching strategies & $43(84.3)$ & $5(9.8)$ & $3(5.9)$ \\
Instruction on experiential teaching strategies & $27(54.0)$ & $13(26.0)$ & $10(20.0)$ \\
Instruction on non-teaching aspects of academia & $48(94.1)$ & $1(2.0)$ & $2(3.9)$ \\
Learning objectives, development & $25(50.0)$ & $14(28.0)$ & $11(22.0)$ \\
Mentoring or advising & $21(42.0)$ & $15(29.4)$ & $14(28.0)$ \\
Syllabus preparation, didactic & $24(49.0)$ & $17(34.7)$ & $8(16.3)$ \\
Syllabus preparation, experiential & $10(20.4)$ & $12(24.5)$ & $27(55.1)$ \\
Teaching non-pharmacy learners & $31(62.0)$ & $8(16.0)$ & $11(22.0)$ \\
Teaching portfolio development & & & \\
\hline A & & &
\end{tabular}

Abbreviations: $\mathrm{PPL}=$ Pharmacy practice laboratory, $\mathrm{TLC}=$ Teaching and learning curriculum

${ }^{a} \mathrm{~N}=53$ completers; however, not every completer answered every question

${ }^{\mathrm{b}}$ On a 5 -point scale where $1=$ Very important, $2=$ Important, $3=$ Fairly important, $4=$ Somewhat important, and $5=$ Not important

completing a TLC program as well as the desirability of various components of TLC programs in relation to the hiring process. This study provides guidance to residency and fellowship programs on how to modify the required programming and activities included in TLC programs to increase graduates' marketability when pursuing a faculty position. Additionally, this study helps increase awareness of what department chairs at pharmacy schools perceive are the vital components of TLC programs, which can then guide pharmacy faculty candidates in enhancing their competitiveness and provide feedback to the Academy regarding the utility of TLC programs. Although pharmacy practice chairs' perception of the utility of TLC programs was generally positive, several other hiring variables, such as relevant practice experiences and publications, were rated as more important. One potential reason for this could be the overall lack of standardization for the quality of TLC programing. A recent survey of the landscape of college-sponsored TLC programs revealed considerable variability among programs across the country. ${ }^{3}$ Pharmacy practice chairs may not be familiar with the requirements of the specific TLC program an applicant has completed, thereby decreasing its importance in the hiring decision. These results may provide feedback to TLC program coordinators to take additional steps to ensure consistent quality and increase awareness of the role of TLC programs in preparing future faculty members. Future research should also focus on evaluating the teaching skills of program participants rather than on their selfperceived improvement and confidence in their skills. The long-term outcomes of TLC participants, including their overall success in academia, have not been well described in the literature.

This study has several limitations. First, the overall response rate was $41.7 \%$, which may decrease the generalizability of our findings. However, this response rate was similar to that obtained from a past national survey of department chairs (46.5\%). ${ }^{37}$ There were a few demographic differences between participants in that survey and those in our survey. Specifically, the department chairs in our sample were more likely to identify as female and less likely to hold a $\mathrm{PhD}$ than participants in the previous study, which included chairs of departments other than pharmacy practice. Notably, AACP's 20192020 Profile of Pharmacy Faculty suggests that about 


\section{American Journal of Pharmaceutical Education 2020; 84 (12) Article 7981.}

$52 \%$ of pharmacy practice department chairs were female, which is similar to our sample. ${ }^{40}$ Our sample was somewhat overrepresented by programs located in the South (about $46 \%$ vs 38\% nationally) and Midwest (about $31 \%$ vs $22 \%$ nationally). However, other factors (eg, private school representation, number of graduated classes, and class size) were similar to the Academy as a whole. ${ }^{30,41}$ Overall, these findings suggest that the risk for nonresponse bias is low. Additionally, our study focused on pharmacy practice chairs; therefore, our findings may not be generalizable to chairs of other academic departments within pharmacy education. However, this could stimulate the evaluation of other variables in the hiring process for nonclinical faculty members within other departments. Finally, we did not ask participants whether their institution sponsored a TLC program. If they did, that could be a potential source of response bias. Nearly all participants had been involved in TLC programs as organizers, presenters, or mentors, and undoubtedly those experiences influenced their perceptions and responses. While there are limitations to this study, it is the first to highlight pharmacy practice chairs' perception of the utility of a faculty candidate having completed a TLC program. Given that most participants in TLC programs ultimately do not initially pursue a full-time faculty position, $, 13,42$ a logical next step would be to conduct a similar, national survey to determine how TLC programs can best meet the needs of non-academic, clinical employers.

\section{CONCLUSION}

Teaching and learning curriculum programs may provide foundational experiences for their graduates that allow the pharmacists to stand out among other candidates for faculty positions. However, department chairs vary in their perceptions of the value of TLC experiences as a whole. In evaluating all qualifications for faculty employment, TLC programs were identified as being of similar importance to non-teaching components, such as a cover letter or letter of intent and board certification. This suggests that TLC programs are only one component of the overall qualitative evaluation of faculty candidates. The TLC program activities that pharmacy practice chairs perceived as most important were instruction in didactic and experiential teaching strategies and experience in developing learning objectives, developing examination items, evaluating examination results, and facilitating case conference or practice laboratory activities.

\section{REFERENCES}

1. Wright EA, Brown B, Gettig J, et al. Teaching and learning curriculum programs: recommendations for postgraduate pharmacy experiences in education. Am J Health Syst Pharm. 2014;71(15): 1292-1302.
2. Havrda DE, Engle JP, Anderson SM, et al. Guidelines for resident teaching experiences. Pharmacotherapy. 2013;33(7):e147-e161. 3. Sheehan AH, Sprunger TL, Viswesh V, Getting JP, Boyle J. The current landscape of college-sponsored postgraduate teaching and learning curriculum programs. Am J Pharm Educ. 2020;84(7):Article 7803.

4. Islam M, Bagheri R, Lung L, Park SY, Talukder R. Status of teaching certificate programs offered by US colleges of and schools of pharmacy [published online ahead of print (April 20, 2019)].

Health Prof Educ. https://www.sciencedirect.com/science/article/pii/ S2452301118301524. Accessed November 23, 2020.

5. American Society of Health-Systems Pharmacists. Accreditation Standards for PGY1 Pharmacy Residencies. https://www.ashp.org/ Professional-Development/Residency-Information/Residency-

Program-Resources/Residency-Accreditation/Accreditation-Standardsfor-PGY1-Pharmacy-Residencies. Accessed November 23, 2020.

6. Castellani V, Haber SL, Ellis SC. Evaluation of a teaching certificate program for pharmacy residents. Am J Health Syst Pharm. 2003;60(10):1037-1041.

7. Sylvia LM. Mentoring prospective pharmacy practice faculty: a seminar series on teaching for pharmacy residents. Am J Pharm Educ. 2004;68(2):Article 38.

8. Romanelli F, Smith KM, Brandt BF. Teaching residents how to teach: a scholarship of teaching and learning certificate program (STLC) for pharmacy residents. Am J Pharm Educ. 2005;69(2):Article 20. 9. Gettig JP, Sheehan AH. Perceived value of a pharmacy resident teaching certificate program. Am J Pharm Educ. 2008;72(5):Article 104. 10. Medina MS, Herring HR. An advanced teaching certificate program for postgraduate year 2 residents. Am J Health Syst Pharm. 2011;68(23):2284-2286.

11. Gonzalvo JD, Ramsey DC, Sheehan AH, Sprunger TL. Redesign of a statewide teaching certificate program for pharmacy residents. Am J Pharm Educ. 2013;77(4):Article 79.

12. Johnson MS, Clements JN. Four years of experiences of a joint school of pharmacy and school of education pharmacy residency teaching certificate program for affiliated residency programs. Curr Pharm Teach Learn. 2013;5(4):276-282.

13. Nappi JM. An academician preparation program for pharmacy residents. Am J Pharm Educ. 2013;77(5):Article 101.

14. Wahl KR, Margolis A, Lintner K, Hartkopf K, Martin B. Impact and application of material learned in a pharmacy residency teaching certificate program. Am J Pharm Educ. 2014;78(6):Article 123.

15. Garrison GD, Baia P, Canning JE, Strang AF. An asynchronous learning approach for the instruction component of a dual-campus pharmacy resident teaching program. Am J Pharm Educ. 2015;79(2): Article 29.

16. Strang AF, Baia P. An investigation of teaching and learning programs in pharmacy education. Am J Pharm Educ. 2016;80(4): Article 59.

17. Sheehan AH, Gonzalvo JD, Ramsey DC, Sprunger TL. Teaching certificate program participants' perceptions of mentor-mentee relationships. Am J Pharm Educ. 2016;80(3):Article 42.

18. Fox J, Clements JN, Sarigianis A. Description and perspective of an academic learning experience for a pharmacy practice resident. Curr Pharm Teach Learn. 2013;5(5):483-489.

19. Wesner AR, Pierce R, Slater N, Johnson M. Evolution of a regional pharmacy residency teaching and learning curriculum program. Curr Pharm Teach Learn. 2016;8(4):469-476.

20. Kominsky BM, Benitez LL, Bostwick JR, Early CR, Klein KC. Benefits of a concentrated teaching rotation: perspectives of pharmacy residents and faculty. Curr Pharm Teach Learn. 2017;9(1):4-8. 


\section{American Journal of Pharmaceutical Education 2020; 84 (12) Article 7981.}

21. Kirdahy K, Turner S, Williams J. Description of an academic teaching rotation for postgraduate year 1 pharmacy residents. Am J Health Syst Pharm. 2012;69(3):228-231.

22. Lis JE, Martin BA, Margolis AR, Barnett SG, Kopacek KJ. Evaluation of a required teaching rotation for pharmacy residents at a school of pharmacy. Curr Pharm Teach Learn. 2014;6(1):158-166. 23. Ray SM, Wheeler JS, Byrd DC. A longitudinal learning experience to prepare residents for a career in academia. Curr Pharm Teach Learn. 2013;5(6):645-650.

24. Slazak EM, Zurick GM. Practice-based learning experience to develop residents as clinical faculty members. Am J Health Syst Pharm. 2009;66(13):1224-1227.

25. Howard ML, Steuber TD, Walton AM, Nisly SA. Pharmacy residents as primary educators with a professional pharmacy elective. Curr Pharm Teach Learn. 2017;9(5):862-868.

26. Messinger NJ, Buring SM. Development of an ambulatory care pharmacy elective by a second-year pharmacy resident. Curr Pharm Teach Learn. 2015;7(5):676-683.

27. Jung CM, Ansara ED, Degenkolb KE, Walroth TA, Williams KE. Development of a precepting workshop for pharmacy residents. Am J Health Syst Pharm. 2016;73(3):127-132.

28. Guillema S, Ly A-V. A pharmacy practice residency (PGY1) with an emphasis on academia. Am J Pharm Educ. 2009;73(1):Article 13.

29. Korte C, Smith A, Pace H. Residency program director's view on the value of teaching. J Pharm Pract 2016;29(4):415-420.

30. Accreditation Council for Pharmacy Education. Programs by

State. https://www.acpe-accredit.org/accredited-programs-by-state.

Accessed November 23, 2020.

31. Wanat MA, Fleming ML, Fernandez JM, Garey KW. Education, training, and academic experience of newly hired, first-time pharmacy faculty members. Am J Pharm Educ. 2014;78(5):Article 92.

32. Smith L, Hansen BK, Heubel E. Common teaching activities and self-perceived teaching proficiency in PGY2 residences. Curr Pharm Teach Learn. 2017;9(2):217-223.

33. Kimberlin CL, Winterstein AG. Validity and reliability of measurement instruments used in research. Am J Health Syst Pharm. 2008;65(23):2276-2284.
34. Jamshed S. Qualitative research method-interviewing and observation. J Basic Clin Pharm. 2014;5(4):87-88.

35. Koo TK, Li MY. A guideline of selecting and reporting intraclass correlation coefficients for reliability research. J Chiropr Med. 2016; 15(2):155-163.

36. Draugalis JR, Plaza CM. Best practices for survey research reports revisited: implications of target population, probability sampling, and response rate. Am J Pharm Educ. 2009;73(8):Article 142.

37. Schwinghammer TL, Rodriguez TE, Weinstein G, et al. AACP strategy for addressing the professional development needs of department chairs. Am J Pharm Educ. 2012;76(6): Article S7.

38. Bennett C, Khangura S, Brehaut JC, Graham ID, Moher D, Potter BK, et al. Reporting guidelines for survey research: an analysis of published guidance and reporting practices. PLoS Med. https://journals.plos.org/plosmedicine/article? id $=10.1371 /$ journal.pmed.1001069. Accessed November 23, 2020 .

39. Bresee LC. An introduction to developing surveys for pharmacy practice research. Can J Hosp Pharm. 2014;67(4):286-291.

40. American Association of Colleges of Pharmacy (AACP) Office of Institutional Research and Effectiveness. 2019-20 Profile of Pharmacy Faculty. https://www.aacp.org/system/files?file=2020-02/ PPF1920-final2.pdf\&Token =7B6EC20E-A55C-4D7E-950535470B7A5E29. Accessed November 23, 2020.

41. American Association of Colleges of Pharmacy (AACP). Academic Pharmacy's Vital Statistics. https://aacp.org/article/ academic-pharmacys-vital-statistics. Accessed November 23, 2020.

42. Shin TR, Clark Dula CA, Metha BH, Rodis JL, Pruchnicki MC. Pharmacy residents' pursuit of academic positions. Am J Pharm Educ. 2015;79(3):Article 38.

43. Knight P, Yorke M. Learning, Curriculum and Employability in Higher Education. $1^{\text {st }}$ edition. London, UK: Taylor \& Francis Group; 2003. https://www.taylorfrancis.com/books/e/9780203465271.

Accessed November 23, 2020. 